\title{
INVESTIGATION OF HEALTH INSURANCE COSTS OF THE PATIENTS WITH MILD COVID-19 SYMPTOMS IN EMERGENCY ROOM
}

\author{
Durmus Ensar, Guneysu Fatih, Guner Gokhan Necip, Aslan Nuray, Yurumez Yusuf \\ Emergency service department, Sakarya University Training and Research Hospital, Adapazari, Sakarya, Turkey
}

Primljen/Received 12. 08. 2021. god.

Abstract: Introduction: This study aims to understand the burden of invoice costs of outpatients with mild Covid-19 symptoms on Social Security Institution (SSI); also, how it may have influenced the current economic situation.

Material and Method: This research is a cross-sectional, retrospective, and descriptive study. The study universe includes the cases who applied to the emergency room (ER) with the symptoms of Covid-19. The sample group was the patients who applied to the Sakarya Training and Research Hospital (SEAH) pandemic ER between 01/09/2020 and 30/06/2021.

Results: During the study period, 130,975 patients were admitted to the pandemic ER. The mean emergency service bill of the cases was $\$ 10.6( \pm 9)$, and the lowest was $\$ 2.2$; the highest was $\$ 201.7$. There was a weak but significant positive correlation between the patients' age and invoice amount (spearman $=0.051$, $\mathrm{p}=0.001$ ). It was perceived that the emergency service bills of the inpatients (mean=21.9 \$) were more than twice that of the outpatients (mean=10.3\$).

Conclusion: In pandemic ER, mild symptomatic young patients' bills can be cheap. It was observed that emergency physicians did not apply too many tests and imaging methods in this patient group and were content only with Rt-PCR scanning. Also, ER bills can increase with age.

Keywords: Covid-19, pandemics, emergency service, costs.

\section{INTRODUCTION}

The Covid-19 disease rose in China during the last months of 2019 and spread to other countries quickly, and was declared a pandemic by the World Health Organization (WHO) in early 2020 (1). After this date, some countries have closed borders, limiting
Prihvaćen/Accepted 28. 08. 2021. god.

flights, introducing social isolation rules, and curfews to decrease the spread rate (2).

A historical discount in oil prices, a reduction in industrial production, automobile and restaurant sales, and as a result, it was seen that unemployment rates reached double digits in many countries during the Covid-19 pandemic (3). Therefore many employees experienced losses in their monthly income and welfare (4). At the same time, the health sector was adversely affected by this financial contraction in some countries. The decrease in hospital admissions and the holding of elective operations caused a decrease in hospitals' revenues $(5,6)$.

Most people in Turkey have health insurance under the Social Security Institution (SSI); furthermore, this health insurance covers all emergency health services in public hospitals. This study will make an effort to reveal the SSI invoice amounts of the emergency services of Covid-19 suspected patients with mild symptoms. Thus, it aims to understand the burden of invoice costs of outpatients with mild Covid-19 symptoms on SSI; also, how it may have influenced the current economic situation.

\section{MATERIAL AND METHOD}

\section{Research Type}

This research is a cross-sectional, retrospective, and descriptive study. The study universe includes the cases who applied to the emergency room (ER) with the symptoms of Covid-19, and the sample group was the patients who applied to the Sakarya Training and Research Hospital (SEAH) pandemic ER between 01/09/2020 and 30/06/2021.

\section{Definitions}

Pandemic ER is a hospital unit for suspected Covid-19 patients with mild symptoms. In this unit 
tests such as reverse transcription-polymerase chain reaction (Rt-PCR), hemogram, blood gas, d-Dimer, biochemical tests, X-ray, and computed tomography (CT) can be studied. In this ER, health service delivery is provided by general practitioners. Rt-PCR test, hydroxychloroquine, or favipiravir drugs are given in the ER are free of charge and are not billed to SSI. Furthermore, if the patients have social health insurance, the examination fee, all other tests (except Rt-PCR), and the treatments applied are invoiced to the SSI.

The Covid-19 signs such as; dry cough, fever, loss of taste or smell, fatigue, conjunctivitis, nasal congestion, headache, sore throat, different types of skin rash, nausea or vomiting, muscle or joint pain, chills, or dizziness, diarrhea assented to mild symptoms (7).

Since the US Dollar (\$) exchange rate varied considerably during the study period, the arithmetic average of the $\$$ exchange rate of this period was taken and $1 \$=7.85$ Turkish lire.

\section{Inclusion Criteria}

- Patients aged 18 and over,

- Cases who applied to the pandemic ER and were examined,

- Patients whose data could be reached entirely through the automation system of the hospital were included in the research.

\section{Exclusion criteria}

- Cases under the age of 18 ,

- Patients who admitted tooth er units of the hospital except for the pandemic ER,

- Subjects who applied to the pandemic ER and left the hospital without being examined,

- Patients whose SSI invoices could not be reached were excluded from the study.

\section{Data Collection}

Patients' age, gender, Rt-PCR, hemogram, biochemical parameters, d-Dimer, ferritin, CRP, blood gas, X-Ray and computed tomography examination information, hospitalization or outpatient follow-up situation were collected retrospectively from the hospital automation system and patient files. The patients' SSI invoices were obtained from the automation system of the hospital.

\section{Statistical Analysis}

The data were analyzed with the statistic program (IBM SPSS Statistics for Windows, Version 21.0. Armonk, NY: IBM Corp.). The values of Skewness and Kurtosis were demanded to to be in the range of $-2 /+$
2 for the data's normal distribution (8). The independent t-test was applied to compare the values of two independent groups with normal distribution, and the Pearson Chi-Square test was utilized to compare categorical data; moreover, a $p$-value $<0.05$ was considered statistically significant. Spearman correlation test was used for correlation analysis within data groups that did not arrange the normal distribution.

\section{Ethics Approval and Permissions}

Approval for this study was obtained from the Sakarya University Faculty of Medicine Ethics Committee [IRB numbers: 71522473/050.01.04].

\section{RESULTS}

During the study period, 130,975 patients were admitted to the pandemic ER, and the mean age was 37.6 years $(\mathrm{SD}=14, \min =18, \max =108)$, and the median age was 35 . Of these patients, 73,534 (56.1\%) were male, and $57441(43.9 \%)$ were female. When comparing patients' age with patients' gender, the mean age of female cases was statistically higher $[\mathrm{t}(118837)=-16.9, \mathrm{p}=0.001]$.

The number of tests requested from the patients is presented in Table 1. Accordingly, hemogram ( $\mathrm{x} 2=$ $377, \mathrm{SD}=1, \mathrm{p}=0.001)$, biochemical parameters $(\mathrm{x} 2$ $=376, \mathrm{SD}=1, \mathrm{p}=0.001), \mathrm{d}$-Dimer $(\mathrm{x} 2=360, \mathrm{SD}=$ $1, p=0.001)$, ferritin $(x 2=364, S D=1, p=0.001)$, CRP ( $\mathrm{x} 2=367, \mathrm{SD}=1, \mathrm{p}=0.001)$, blood gas tests $(\mathrm{x} 2=89, \mathrm{SD}=1, \mathrm{p}=0.001)$ as number and ratio was significantly more studied between the female gender; Rt-PCR ( $22=40, \mathrm{SD}=1, \mathrm{p}=0.001), \mathrm{X}$-ray $(\mathrm{x} 2=127$, $\mathrm{SD}=1, \mathrm{p}=0.001)$ and $\mathrm{CT}(\mathrm{x} 2=56, \mathrm{SD}=1, \mathrm{p}=0.001)$ were applied more in the male gender.

The mean age of the patients whose hemogram, biochemical parameters, d-Dimer, ferritin, CRP, blood gas, X-ray, and CT tests were studied was found to be significantly higher [respectively; $\mathrm{t}(13575)=-87, \mathrm{p}=$ $0.001, \mathrm{t}(13504)=-88, \mathrm{p}=0.001, \mathrm{t}(12080)=-87, \mathrm{p}=$ $0.001, \mathrm{t}(12087)=-87, \mathrm{p}=0.001, \mathrm{t}(12973)=-87, \mathrm{p}=$ $0.001, \mathrm{t}(4041)=-46, \mathrm{p}=0.001, \mathrm{t}(12727)=-28, \mathrm{p}=$ $0.001, t(6810)=-79, p=0.001]$. On the other hand, it was observed that the mean age of the patients who underwent Rt-PCR test was younger than the patients who did not $[t(16185)=35, p=0.001]$.

The mean emergency service bill of the cases was $\$ 10.6( \pm 9)$, and the lowest was $\$ 2.2$; the highest was $\$ 201.7$. There was a weak but significant positive correlation between the patients' age and invoice amount (spearman $=0.051, \mathrm{p}=0.001$ ).

The average bill for women was $\$ 10.7$, while men's was $\$ 10.5$. However, it was determined that the 
Table 1. Crosstab of applied tests count and patients'gender

\begin{tabular}{|c|c|c|c|c|c|c|c|}
\hline \multirow{4}{*}{ Test } & \multicolumn{4}{|c|}{ Gender } & \multirow{2}{*}{\multicolumn{2}{|c|}{ Total }} & \multirow{4}{*}{$p$-value } \\
\hline & \multicolumn{2}{|c|}{ Male } & \multicolumn{2}{|c|}{ Female } & & & \\
\hline & Yes & No & Yes & No & Yes & No & \\
\hline & $\mathrm{n}(\%)^{\mathrm{b}}$ & $\mathrm{n}(\%)^{\mathrm{b}}$ & $\mathrm{n}(\%)^{\mathrm{b}}$ & $\mathrm{n}(\%)^{\mathrm{b}}$ & $\mathrm{n}(\%)^{\mathrm{b}}$ & $\mathrm{n}(\%)^{\mathrm{b}}$ & \\
\hline Hemogram & $5740(8)$ & $67794(92)$ & $6276(11)$ & $51165(89)$ & $12016(9)$ & $118959(91)$ & 0.001 \\
\hline Biochemical & $5708(8)$ & $67826(92)$ & $6245(11)$ & $51196(89)$ & $11953(9)$ & $119022(91)$ & 0.001 \\
\hline d-Dimer & $5127(7)$ & $68407(93)$ & $5675(10)$ & $51766(90)$ & $10802(8)$ & $120173(92)$ & 0.001 \\
\hline Ferritin & $5128(7)$ & $68406(93)$ & $5686(10)$ & $51755(90)$ & $10814(8)$ & $120161(92)$ & 0.001 \\
\hline CRP & $5504(8)$ & $68030(93)$ & $6036(11)$ & $51405(90)$ & $11550(9)$ & $119435(92)$ & 0.001 \\
\hline Rt-PCR & $66227(90)$ & $7307(10)$ & $51117(89)$ & $6324(11)$ & $117334(90)$ & $13541(10)$ & 0.001 \\
\hline Blood Gas & $1894(3)$ & $71640(97)$ & $1992(4)$ & $55449(97)$ & $3886(3)$ & $127089(97)$ & 0.001 \\
\hline X-ray & $5625(8)$ & $67909(92)$ & $5396(9)$ & $52045(91)$ & $11021(8)$ & $119954(92)$ & 0.001 \\
\hline $\mathrm{CT}$ & $3273(5)$ & $70261(96)$ & $3070(5)$ & $54371(95)$ & $6343(5)$ & $124632(95)$ & 0.001 \\
\hline
\end{tabular}

aPearson Chi-Square test results, ${ }^{\text {b }}$ Percent within patients' gender.

average invoice cost of the patients in 2020 (mean $=$ $14.7 \$$ ) was more than three times the average invoice price in 2021 (mean $=4.6 \$)$. CT was utilized for 4229 (5.4\%) patients in 2020; moreover, for 2114 (4\%) patients in 2021. It was observed that the number and rate of CT scans decreased over the years.

In $2020,912(1.2 \%)$ of 77,669 patients were hospitalized, and $1029(1.9 \%)$ of 53,306 patients were hospitalized in 2021. A significant difference was determined in the number of hospitalizations by years $(\mathrm{x} 2=124, \mathrm{SD}=1, \mathrm{p}=0.001)$. Accordingly, it was recognized that the number and rate of hospitalized patients increased. The age of the patients affected the hospitalization status, and the mean age of the hospitalized patients $($ mean $=57.5)$ was detected to be significantly higher than that of the outpatients (mean $=$ 37.3) $[\mathrm{t}(1995)=-61, \mathrm{p}=0.001]$. Besides, it was perceived that the emergency service bills of the inpatients $($ mean $=21.9 \$)$ were more than twice that of the outpatients $($ mean $=10.3 \$)$.

\section{DISCUSSION}

Studies in the literature on health insurance costs of patients admitted to emergency services with the suspicion of COVID-19 are very limited. In a study conducted by Edwine Barasa et al. in Kenya, it was stated that the follow-up of asymptomatic and mildly symptomatic COVID-19 patients in the hospital instead of at home increases the treatment costs up to four times (9). In the same study, it was published that the cost of the treatment increased approximately six times when patients were admitted to the general hospital wards (9). It was noticed that the mild symptomatic outpatients' invoice costs were lower than those who were decided to be hospitalized in our study. Although patients' bills after hospitalization were out of our scope, the high invoice costs in the ER were in line with the above research results.

Carmen Guadalupe Rodriguez-Gonzalez et al. notified that the risk of ARDS rises with increasing age in Covid-19 patients receiving hospital treatment in Spain; moreover, the Covid-19 treatment was 408 Euros per patient (10). Erhan Ekingen and Ahmet Yildiz described in their study on the treatment costs of Covid-19 patients hospitalized in Turkey that the average cost per person was $\$ 653$; also, this cost was higher in patients over 65 years of age (11). For nonCovid-19 patients, Behcet Varislı et al. informed that the bills of the patient group over the age of 85 who applied to the emergency department were more expensive than the younger cases (12).

Moran Dong et al. pointed that the average treatment cost of hospitalized Covid-19 patients was around \$2869 per patient, and the treatment costs were higher in males and the elderly in China (13). In another study conducted in China, the average cost of treatment for Covid-19 patients aged 0-34 was \$2752, and \$11668 for patients over 70 years of age (14). According to our study results, it was observed that insurance costs rise in parallel with the increasing age of the patients. In this respect, our study coincides with the results of the above study. The increase in mortality with age, the more insidious course of Covid-19 pneumonia in elderly patients, and the more frequent observation of severe disease in the elderly, and the need for further examination of elderly patients may explain the increase in the cost of bills in the emergency department with age (15-18). On the other hand, in contrast to Mo- 
ran Dong et al., a slightly higher invoice cost was seen in the female gender in our study.

The fact that young patients with mild symptoms applied to the ER in the pandemic may have brought the low number of expensive examination requests such as CT. While Rt-PCR was tested in $90 \%$ of the cases, simple laboratory tests such as hemogram were only $10 \%$ of all patients, and the CT rate was $5 \%$ might have caused the low pandemic emergency bills of young mildly symptomatic patients.

\section{CONCLUSION}

In pandemic ER, mild symptomatic young patients' bills can be cheap. It was observed that emergency physicians did not apply too many tests and imaging methods in this patient group and were content only with Rt-PCR scanning. Also, ER bills can increase with age.

\section{Acknowledgment}

None.

Conflict of Interests: The authors declare that there are no conflicts of interest related to this article.

Funding: None

Author contributions: Conception and design-NA, ED, YY; Acquisition of data: FG, NGG, YY, NA; Analysis and interpretation of data: FG, NGG, ED; Drafting the article: NA, ED, YY; Critical Revision: FG, NGG, YY; Final approval: NA, ED, NGG, FG, YY; Agreement to be accountable for all aspects of the work:NA, ED, NGG, FG, YY.

\section{Licensing}

This work is licensed under a Creative Commons Attribution 4.0 International (CC BY 4.0) License.

\title{
Sažetak
}

\section{ISTRAŽIVANJE TROŠKOVA ZDRAVSTVENOG OSIGURANJA PACIJENTA SA BLAGIM SIMPTOMIMA KOVID-19 U HITNOJ SLUŽBI}

\author{
Durmus Ensar, Guneysu Fatih, Guner Gokhan Necip, Aslan Nuray, Yurumez Yusuf \\ Emergency service department, Sakarya University Training and Research Hospital, Adapazari, Sakarya, Turkey
}

Uvod: Cilj ove studije je da shvati teret fakturnih troškova ambulantnih pacijenata sa blagim simptomima Kovid-19 u Zavodu za socijalno osiguranje (SSI); takođe, kako je to moglo uticati na trenutnu ekonomsku situaciju.

Materijal i metode: Ovo istraživanje je studija preseka, retrospektiva i deskriptivna studija. Studija uključuje slučajeve koji su primljeni u Službu hitne pomoći (ER) sa simptomima Kovid-19. Ispitivanu grupu čine pacijenti koji su se javili u Sakaria Bolnicu za Obuku i Istraživanje (Sakarya Training and Research Hospital (SEAH)) u periodu od 1. 9. 2020. do 30. 6. 2021.

Rezultati: Tokom perioda istraživanja, 130.975 pacijenata je primljeno u pandemijsku Službu hitne pomoći. Prosečan račun Hitne službe u ovim slučajevima iznosio je 10,6 USD ( \pm 9), a najniži 2,2 USD;

\section{REFERENCES}

1. WHO announces COVID-19 outbreak a pandemic 2020 http:/www.euro.who.int/en/health-topics/health-emergencies/ coronavirus-covid-19/news/news/2020/3/who-announcescovid-19-outbreak-a-pandemic (accessed April 11, 2020).

2. Durmus E, Guneysu F. The effect of Curfew enforcement on healthcare provision in COVID-19 Pandemic. J INFO Kesehat. 2020; 18(2): 182-8. doi:10.31965/invokes.Vol18. Iss2.483. najveći je iznosio 201,7 dolara. Postojala je slaba, ali značajna pozitivna korelacija između starosti pacijenata $\mathrm{i}$ iznosa fakture (Sperman $=0,051, \mathrm{p}=0,001$ ). Uočeno je da su računi za hitnu pomoć stacionarnih pacijenata (srednja vrednost $=21,9$ USD) više nego dvostruko veći od troškova ambulantnih pacijenata (srednja vrednost $=10,3$ USD).

Zaključak: U pandemijskoj Hitnoj pomoći, računi mlađih pacijenata sa blagim simptomima mogu biti jeftini. Uočeno je da lekari Hitne pomoći nisu primenili previše testova i metoda snimanja u ovoj grupi pacijenata i bili su zadovoljni samo Rt-PCR skeniranjem. Računi Hitne pomoći mogu da se povećavaju sa godinama.

Ključne reči: Kovid-19, pandemija, Hitna pomoć, troškovi.

3. Yamin M. Counting the cost of COVID-19. Int J Inf Technol. 2020; 12: 311-7. doi:10.1007/s41870-020-00466-0.

4. Coibion O, Gorodnichenko Y, Weber M. The cost of the Covid-19 crisis: lockdowns, macroeconomic expectations, and consumer spending. Cambridge, MA: National Bureau of Economic Research; 2020. doi:10.3386/w27141.

5. Bai G, Zare H. Hospital cost structure and the implications on cost management during COVID-19. J Gen Intern Med. 2020; 35(9): 2807-9. doi:10.1007/s11606-020-05996-8. 
6. Durmus E, Guneysu F. Effect of COVID-19 on the admissions to the adult emergency department. J Contemp Clin Pract. 2020; 6(2): 58-63. doi:10.18683/jccp.2020.1057.

7. Corona virus disease (COVID-19) 2020. https://www. who.int/news-room/q-a-detail/coronavirus-disease-covid-19 (accessed May 2, 2021).

8. George D, Mallery P. IBM SPSS statistics 25 step by step: a simple guide and reference. Fifteenth edition. New York; London: Routledge, Taylor \& Francis Group; 2019.

9. Barasa E, Kairu A, Ng'ang'a W, Maritim M, Were V, Akech S, et al. Examining unit costs for COVID-19 case management in Kenya. BMJ Glob Health. 2021; 6(4): e004159. doi:10.1136/bmjgh-2020-004159.

10. Rodriguez-Gonzalez CG, Chamorro-de-Vega E, Valerio M, Amor-Garcia MA, Tejerina F, Sancho-Gonzalez M, et al. COVID-19 in hospitalized patients in Spain: a cohort study in Madrid. Int J Antimicrob Agents. 2021; 57(2): 106249. doi:10.1016/j.ijantimicag.2020.106249.

11. Ekingen E, Yildiz A. COVID-19 Treatment costs in Turkey: determinants and burden of the social security institution. İktisadi İdari Ve Siyasal Araştırmalar Derg. 2021; 6(15): 262-70. doi:10.25204/iktisad.844714.

12. Varisli B, Dogan FS, Yigitbas MR. Examination of geriatric patients who presented to the emergency department in terms of clinical, demographic and cost. Anatol J Emerg Med. 2018; 1(2): 18-24.

\section{Correspondence to/Autor za korespondenciju}

Dr Ensar Durmus

Institution: Sakarya University Training and Research Hospital

Department: Emergency Service

Adress: Sakarya University Training and Research Hospital Emergency Service

Adapazari/ Sakarya/ Turkey.

Postal Code: 54200

Phone Number: +90 2648884000

Fax Number: +90 2642759192

Mobile Phone Number: +90 5058665782

e-mail: ensar.durmus@saglik.gov.tr

ORCID NO: 0000-0001-7722-6639
13. Dong M, Yang Z, Chen Y, Sun J, Ma W, Cheng S, et al. Hospitalization costs of COVID-19 cases and their associated factors in Guangdong, China: a cross-sectional study. Front Med (Lausanne). 2021; 8: 655231. doi: 10.3389/fmed.2021.655231.

14. Li XZ, Jin F, Zhang JG, Deng YF, Shu W, Qin JM, et al. Treatment of coronavirus disease 2019 in Shandong, China: a cost and affordability analysis. Infect Dis Poverty. 2020; 9(1): 78. doi:10.1186/s40249-020-00689-0.

15. Zhou F, Yu T, Du R, Fan G, Liu Y, Liu Z, et al. Clinical course and risk factors for mortality of adult inpatients with COVID-19 in Wuhan, China: a retrospective cohort study. Lancet. 2020; 395 (10229): 1054-62. doi:10.1016/S01406736(20)30566-3.

16. Onder G, Rezza G, Brusaferro S. Case-fatality rate and characteristics of patients dying in relation to COVID-19 in Italy. JAMA. 2020; 323(18): 1775-6. doi: 10.1001/jama.2020.4683. Erratum in: JAMA. 2020; 323(16): 1619.

17. Dai M, Bao M, Chen X, Zhang Q, Jian Y. Middle-aged and elderly patients with COVID-19 pneumonia arising from asymptomatic carriers: A report of six cases. Med Comm. 2020; 1(3): 420-2. doi:10.1002/mco2.35.

18. Zou Y, Guo H, Zhang Y, Zhang Z, Liu Y, Wang J, et al. Analysis of coagulation parameters in patients with COVID-19 in Shanghai, China. Biosci Trends. 2020; 14(4): 285-9. doi: 10.5582/bst.2020.03086. 